\title{
The impacts of Covid-19 on the major mining municipalities in Brazil ${ }^{3}$
}

\begin{abstract}
Fernando Ferreira de Castro ${ }^{1}$
José Antônio Sena do Nascimento ${ }^{1}$

Geraldo Sandoval Góes ${ }^{2}$

Mônica Tardin Monnerat ${ }^{1}$

${ }^{1}$ Researcher at Mineral Technology Center (CETEM - MCTI), Rio de Janeiro, Rio de Janeiro, Brazil

${ }^{2}$ Researcher at Institute of Applied Economic Research (IPEA), Rio de Janeiro, Rio de Janeiro,

Brazil
\end{abstract}

This paper discusses the influences of mining on the spread of the new coronavirus in the largest mining municipalities in Brazil, since its determination as an essential activity to face Covid-19. The theoretical discussion approaches the issue of whether the virus is spreading further or not among workers who have maintained their activities in the mining sector. The objective of this article is to investigate the impact of Covid-19 on mining and whether the maintenance of this activity is related to a higher incidence. To measure incidence rates, the qualitative methodology involved a case study of mining municipalities selected by the amount of royalties collected and for the maintenance of activities by monitoring the supply of jobs during the pandemic. The incidence of cases was georeferenced on maps and the results analyzed by population range. The Sustainable Development Goals (SDGs) applied to the mineral sector were used as a purpose for this investigation. The results found that: (i) among 997 municipalities in the states of Pará and Minas Gerais, the incidence of Covid-19 is relatively higher in selected mining municipalities; (ii) there is a greater proportion of Covid-19 cases in the selected municipalities than in others in the same population range; (iii) the supply of jobs in the mining sector in the selected municipalities remained stable compared to the period before the pandemic.

Keywords: Brazil, mining, Covid-19.

\section{Os impactos da Covid-19 nos maiores municípios mineradores do Brasil}

Este artigo discute as influências da mineração na disseminação do novo coronavírus nos maiores municípios mineradores do Brasil, desde sua determinação como atividade essencial para o enfrentamento do Covid-19. A discussão teórica aborda a questão da disseminação do

\footnotetext{
3 DOI: https://doi.org/10.21874/rsp.v71i0.4974 Submitted: August 16, 2020. Published: September 1th, 2020.

ISSN: 0034-9240 | E-ISSN: 2357-8017
}

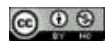


vírus ser maior ou não entre os trabalhadores no setor mineral que mantiveram suas atividades. O objetivo deste artigo é investigar o impacto da Covid-19 na mineração e se a manutenção dessa atividade está relacionada com uma maior incidência da doença. Para mensurar as taxas de incidência, a metodologia qualitativa envolveu um estudo de caso de municípios mineradores selecionados pelo valor dos royalties arrecadados e pela manutenção das atividades por meio do monitoramento da oferta de empregos durante a pandemia. A incidência de casos foi georreferenciada em mapas e os resultados analisados por faixa populacional. Os Objetivos de Desenvolvimento Sustentável (ODS) aplicados ao setor mineral foram utilizados como justificativa desta investigação. Os resultados verificaram que: (i) entre 997 municípios dos estados do Pará e Minas Gerais, a incidência da Covid-19 é relativamente maior em municípios mineradores selecionados; (ii) há uma proporção maior de casos Covid-19 nos municípios selecionados do que em outros na mesma faixa populacional; (iii) a oferta de empregos no setor de mineração nos municípios selecionados permaneceu estável em comparação com o período anterior à pandemia.

Palavras-chave: Brasil, mineração, covid-19.

\section{Los impactos de Covid-19 en los municipios mineros más grandes de Brasil}

En este artículo se analizan las influencias de la minería en la propagación del nuevo coronavirus en los mayores municipios mineros de Brasil, desde su determinación como actividad imprescindible para enfrentar al Covid-19. La discusión teórica aborda la cuestión de si el virus se está propagando más o no entre los trabajadores del sector minero que mantuvieron sus actividades. El propósito de este artículo es investigar el impacto delCovid-19 en la minería y si el mantenimiento de esta actividad está relacionado con una mayor incidencia de la enfermedad. Para medir las tasas de incidencia, la metodología cualitativa involucró un estudio de caso de municipios mineros seleccionados por el monto de las regalías recaudadas y por el mantenimiento de las actividades mediante el monitoreo de la oferta de empleos durante la pandemia. La incidencia de casos fue georreferenciada en mapas y los resultados analizados por rango poblacional. Los Objetivos de Desarrollo Sostenible (ODS) aplicados al sector minero se utilizaron como justificación para esta investigación. Los resultados encontraron que: (i) entre 997 municipios de los estados de Pará y Minas Gerais, la incidencia de Covid-19 es relativamente mayor en municipios mineros seleccionados; (ii) hay una mayor proporción de casos de Covid19 en los municipios seleccionados que en otros del mismo rango de población; (iii) la oferta de empleo en el sector minero en los municipios seleccionados se mantuvo estable en comparación con el período anterior a la pandemia.

Palabras clave: Brasil, minería, Covid-19 


\section{Introduction}

Brazil is the second country with the largest number of confirmed cases of the new coronavirus pandemic, with more than 3 million accumulated cases and 100,000 deaths registered until August $9^{\text {th }}$ (MS, 2020). The country's public health system can be considered one of the best coverages in Latin America; however, given the challenges of overcoming the vast territorial length and the spread of the disease, the pressure on health institutions has been worrisome.

The pandemic affected the Brazilian economy in three dimensions: (i) strong drop in external demand, caused by the closure of other countries' economies, (ii) reduction in domestic demand, due to the Brazilian economy closure; and (iii) shock in oil prices, which impacted Brazil as a net oil exporter (World Bank, 2020). According to the Brazilian Institute of Geography and Statistics (IBGE, 2020), the combined impact of these three shocks is pushing the economy into a recession. This situation causes chain effects throughout the Brazilian economy, especially in its most vulnerable parts, such as small municipalities and indigenous communities.

Like most countries, Brazil closed a large part of its economy to fulfill the social distancing policy necessary to avoid the spread of the virus, except for some economic activities that were considered essential, including mining. Without specifying which activities in the mining sector would be essential for the maintenance of the country most important activities, it was questioned, specifically for the mining sector, what were the risks of maintaining this activity with a growing spread of Covid-19? Once it was determined that this would be one of the activities kept in operation, it is necessary to assess how mining is affected by the economic scenario in the context of the effects of the pandemic.

The objective of this research is to investigate how mining has been affected and whether maintaining mining activity has increased Covid-19 in the selected mining muncipalities. In particular, with the application of qualitative methodologies for surveying and analyzing socioeconomic and health data, the aim is to assess the incidence of contagion in the selected mining municipalities in comparison with other municipalities, the variation in formal jobs and, finally, which conclusions can be taken as contributions to the decision making of public agents. The hypothesis to be investigated deals with the risks that involve mining as an essential activity, which may contribute to spreading COVID-19 to the interior of the country.

The analysis proposed in this article is justified by the fact that Brazilian mining is characterized as an essential economic activity and with the capacity to mobilize human, physical, technological and financial resources whose performance can contribute to the achievement of the goals of the Sustainable Development Goals (SDG). 
Due to its characteristics of seeking a natural resource, mining activity is often located in remote, ecologically sensitive and less developed areas, including indigenous territories. When effectively managed, it can create jobs, stimulate innovation and bring investment and infrastructure in the long-term. However, if poorly managed, mining can lead to environmental degradation, displacement of populations, inequality, deepening conflicts and increasing local economic dependence on mineral extraction.

The source of income of the population involved in mining is an important aspect related to the SDG's and its consequent effects, such as the health risks that workers in the sector are exposed to while continuing their activities amid the danger of contracting Covid-19. From this approach, a set of actions related to the SDGs was identified that can be useful, if applied, in the context of measures to confront and mitigate the pandemic by decision makers and public managers.

The Appendix I summarizes the interface points of the SDGs with the mineral sector in the context of the Covid-19 pandemic, providing elements for the continuation of studies related to the theme: mining and Covid-19.

In addition to this introduction, this paper approaches in the second section the macroeconomic dimension of the Brazilian mineral sector. The third section shows the normalization of mining as an essential activity. The fourth section presents the databases and the methodology used. The fifth section discusses the results obtained. The sixth section shows the evolution of jobs. Finally, the last section concludes the paper.

\section{Covid-19's impacts on the Brazilian mineral sector}

The effects of the Covid-19 Pandemic were remarkable throughout the world and considerably affected the Brazilian economy in several aspects, especially those related to international trade, which in the specific case of Brazil are strongly dependent on the export of Mineral commodities. These effects can be assessed by the amount of mineral production, collection of royalties, entitled as Financial Compensation for the Exploration of Mineral Resources (CFEM), in terms of jobs supply and among others, which are useful indicators to measure the dimension of the effects of the pandemic in the economic scenario regarding mineral resources.

The Covid-19 epidemic impacted the performance of the Brazilian mineral economy by reducing the demand for exports of Brazilian ores (until April 2020), the drop in the price of ores (except for gold) together with the worsening in terms of trade, due to an increase in market volatility and a consequent increase in global risk aversion (with a strong negative reaction in the 
prices of mineral assets). In addition, the reduction in the flow of people and goods as a result of social distancing policies affected both the demand side and the supply side of the mineral market.

Table 1 summarizes the drop in Brazilian mineral production in the first quarter of 2020 , when it reached 220.4 million tons, which represents a $17.7 \%$ drop compared to the previous quarter and a $17.0 \%$ drop compared to the same quarter in 2019.

Table 1. Percentage of Brazilian Mineral Production (BMP), in millions of tons.

\begin{tabular}{lccccc}
\hline \hline & $1^{\text {st }} \mathbf{q} / 19$ & $\mathbf{4}^{\text {th }} \mathbf{q} / 19$ & $\mathbf{1}^{\text {st } q / 20}$ & $\begin{array}{c}\text { Relative to } \\
\text { the } \\
\text { previous } \\
\text { quarter (\%) }\end{array}$ & $\begin{array}{c}\text { Relative to the } \\
\text { quarter of the } \\
\text { previous year (\%) }\end{array}$ \\
\hline $\begin{array}{l}\text { BMP } \\
\text { (millions of tons) }\end{array}$ & 265,5 & 267,8 & 220,4 & $-17,7$ & $-17,0$ \\
\hline \hline
\end{tabular}

Source: IBRAM (2020). Prepared by ECOMIN/CETEM.

This result can be explained by global and domestic factors. Graph 1 shows, in global terms, the drop in the prices of the main mineral commodities, which is associated with a lower demand for mineral goods worldwide.

Graph 1. Price of the major mineral goods exported between January (2019) and April (2020).

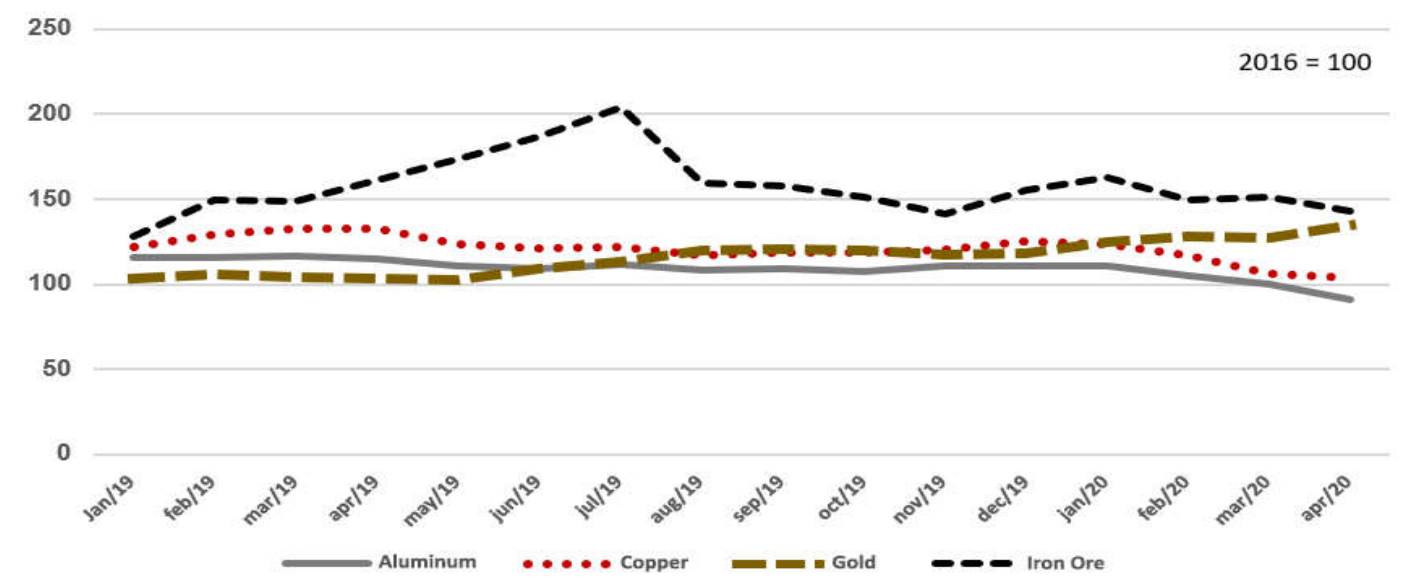

Source: IMF (2020). Prepared by ECOMIN/CETEM.

In addition, the volatility of the international economic environment, especially in regard to logistical restrictions on foreign trade, ended up impacting countries most dependent on exports of mineral commodities, such as Brazil. According to the United Nations Conference on Trade and Development (UNCTAD, 2020), the effects of the Covid-19 pandemic on the economy of emerging 
countries will tend to be worse than those seen in the period following the great recession of 2008/2009.

Among the most traded mineral goods, practically all of them presented a drop in prices in the first quarter of the year (Graph 2), except for gold ore, whose growth approached $8 \%$. Graph 2. Price of metallic commodities (percentage change).

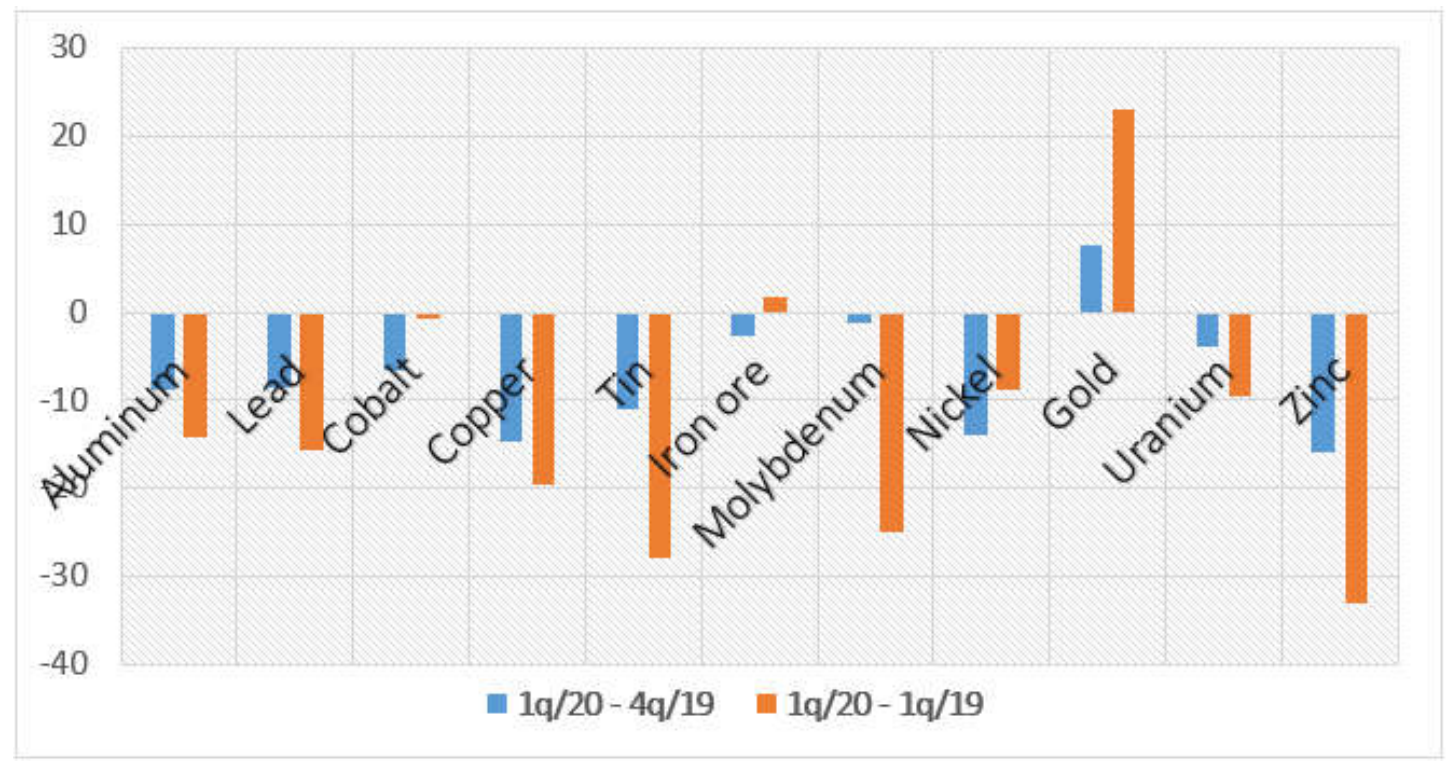

Source: IMF (2020). Prepared by ECOMIN/CETEM. 
The reduction in mineral production in the first quarter of 2020 reflected in the volume and value decrease of mineral exports. In this sense, there is a reduction of approximately $18 \%$ in the volume exported and $13 \%$ in the value exported, when compared to the $4^{\text {th }}$ quarter 2019 (Graph 3).

Graph 3. Brazilian mineral exports (value and physical production).

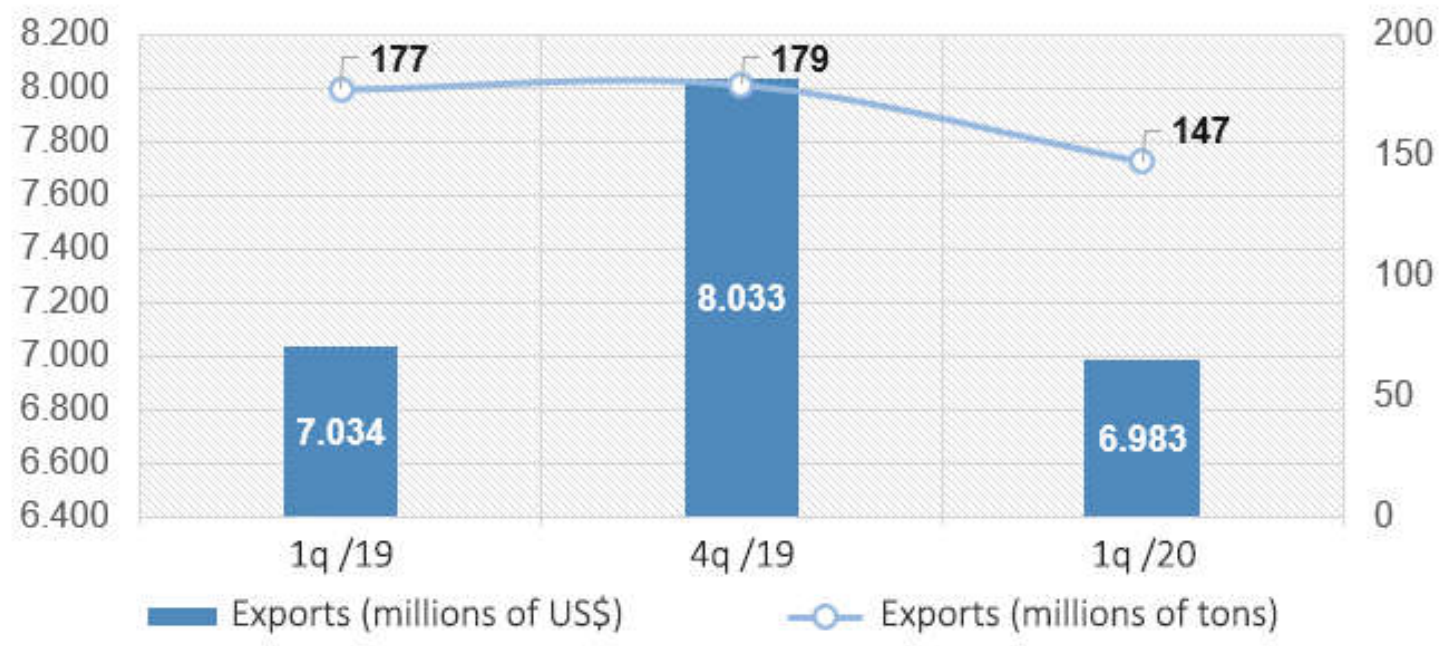

Source: IBRAM (2020).

Iron ore is the most exported mineral product in Brazil (ANM, 2020). In terms of production value, this mineral good ranks second in the world supply and accounts for $64.2 \%$ of mineral exports, according to FMI. In the first quarter of 2020 there was a slight drop in its value, compared to the previous quarter. This reduction caused a lower percentage of iron exports in the total value of mineral exports.

In Brazil, these exports totaled 70.07 million tons in the first quarter of 2020 , which represents a decrease of approximately $17 \%$ compared to the same period in 2019 . In comparison to the fourth quarter of 2019 (88.40 million tons of iron), this reduction was $21 \%$.

In terms of the collection of royalties in Brazil, entitled CFEM (Brasil, 2017), Table 2 below shows an $18 \%$ drop in the first quarter of 2020 , compared to the fourth quarter of 2019 . This reduction is evidenced by the drop in prices of all major mineral substances, with the exception of gold, which grew $14.1 \%$ in the first quarter of 2020. 
Table 2. CFEM collected (in millions of reais).

\begin{tabular}{lcccc}
\hline \hline & $\mathbf{1}^{\text {st }} \mathbf{q}$ & $\mathbf{4}^{\text {th }} \mathbf{q}$ & $\mathbf{1}^{\text {st }} \mathbf{q}$ & $\mathbf{V a r} \mathbf{\%}$ \\
& $\mathbf{I} \mathbf{2 0 1 9}$ & $\mathbf{I 2 0 1 9}^{\text {st }} \mathbf{~} \mathbf{2 0} / \mathbf{4}^{\text {th }} \mathbf{q} \mathbf{1 9}$ \\
\hline Iron ore & 645,8 & 975,2 & 786,7 & $-19,3$ \\
Gold & 50,4 & 53,6 & 61,1 & 14,1 \\
Copper & 43,2 & 60,9 & 45,0 & $-26,1$ \\
Aluminum (Bauxite) & 30,9 & 38,0 & 31,8 & $-16,5$ \\
Total & 876,8 & $1.251,3$ & $1.023,2$ & $-18,2$ \\
\hline \hline
\end{tabular}

Source: IBRAM (2020).

Another important aspect of the pandemic effects is the labor market, which has been impacted worldwide by Covid-19, as the risks to worker's health are aggravated. In addition to this dynamic, informality is a major obstacle for the success of social isolation actions in developing countries (Loayza \& Pennings, 2020). In the Brazilian case, there is a large contingent of workers who do not have social security benefits and other coverages that are provided to those with formal employment.

In this sense, the reorganization of the mining market will depend on the consistent resumption of demand from the main importers of mineral goods, especially Asian nations, such as China. However, health impacts can compromise the economic recovery if the spread of the virus is not controlled. In order to broaden the assessment of the impacts of the pandemic on the mining sector, the assessment should consider the definition of the activity as essential during the pandemic.

\section{The regulation of mineral activities as essential}

One of the first actions taken by the Brazilian government was determining which activities are considered essential, in order to sustain the economy and guarantee the means to overcome Covid-19 proliferation. The essential nature of mining activity was regulated as a consequence of the pandemic, through Law No. 13.979 of February 6 ${ }^{\text {th }}, 2020$ (Brasil, 2020a) and by Decree No. 10.282 of March $20^{\text {th }}, 2020$ (Brasil, 2020b). In Article 3, paragraph 1, it was established that "essential public services and activities are those essential to meeting the urgent needs of the community, thus considered those that, if not met, endanger the survival, health or safety of the community. population, such as: [...] L [50] - mining activities, processing, production, commercialization, flow and supply of mineral goods. " (Brasil, 2020b).

The Ministry of Mines and Energy (MME) added to this regulation action with the Ordinance No. 135 of March $28^{\text {th }}, 2020$ (MME, 2020), that was the first to consider mining, processing, production, commercialization, flow and supply activities of mineral goods as essential in a broad 
way. Finally, Decree No. 10.329 of April 28 ${ }^{\text {th }}, 2020$ (Brasil, 2020c), maintained the decision and ratified the MME ordinance, however it did not specify which types of mining activities are essential, and which are not in this scenario.

From the regulation of this decree, the operation of extractive activity was guaranteed. However, maintaining the operation of the activity to face the health crisis raises some questions: - How will the sector be monitored in the major mining municipalities? - Which mining is effectively essential for the "survival, health or safety of the population"? - What were the consequences observed, since the regulation of the decree, and the incidence of cases in the major mining municipalities in Brazil?

The infection of the Brazilian population by Covid-19 has not been stabilized so far, as it continues to increase and is spreading throughout the wide territory. In the Brazilian mining scenario and considering the current health issues, the response of municipalities to the pandemic should be evaluated. To this end, the methodological steps and data sources used to carry out this investigation will be presented below.

\section{Data sources and methodology}

The qualitative methodology of this research initially involved bibliographic research to assess the economic performance and mining development of Brazil in 2020 and 2019 respectively. The major mining municipalities were selected based on mining royalties collection (CFEM) and such selection was carried out non-randomly for the states of Pará and Minas Gerais (main Brazilian mineral provinces). The next step was the definition of databases for data collection on Covid-19 cases in all municipalities for both states. In parallel, employment data were collected for the year 2019 and 2020 (January to May) in the selected mining municipalities (shown in Metadata ${ }^{29}$ Table 3). The analysis and discussion of the preliminary results for the selected mining municipalities were based on the comparison with other municipalities in the respective states.

\footnotetext{
${ }^{29}$ Special thanks to the anonymous referees of RSP Journal and in particular for the inclusion of the metadata table.
} 
Table 3. Metadata table.

\begin{tabular}{|c|c|c|c|c|}
\hline Topic & Database & $\begin{array}{c}\text { Data collection } \\
\text { (Variables) }\end{array}$ & Period & $\begin{array}{l}\text { Territorial } \\
\text { dimension }\end{array}$ \\
\hline $\begin{array}{l}\text { CFEM } \\
\text { (royalties) }\end{array}$ & $\begin{array}{l}\text { Royalties collection } \\
\text { system (ANM) }\end{array}$ & $\begin{array}{l}\text { Royalties collected } \\
\text { (current values) }\end{array}$ & $\begin{array}{l}2019 \text { (jan.- } \\
\text { dec.) }\end{array}$ & $\begin{array}{c}\text { Selected } \\
\text { Mining } \\
\text { Municipalities } \\
997\end{array}$ \\
\hline Covid-19 & $\begin{array}{l}\text { Painel Coronavírus } \\
\text { (Ministry of Health) }\end{array}$ & $\begin{array}{c}\text { Accumulated cases } \\
\text { (number of cases) }\end{array}$ & $\begin{array}{l}\text { Until } 9 \\
\text { (July 9th, } \\
2020 \text { ) }\end{array}$ & $\begin{array}{c}\text { municipalities } \\
\text { from Pará and } \\
\text { Minas Gerais } \\
\text { state }\end{array}$ \\
\hline $\begin{array}{l}\text { Jobs } \\
\text { supply }\end{array}$ & $\begin{array}{l}\text { CAGED (Ministry of } \\
\text { Economy) }\end{array}$ & $\begin{array}{l}\text { Monthly variation } \\
\text { (admissions and } \\
\text { dismissals) }\end{array}$ & $\begin{array}{c}2019 \text { (jan) } \\
-2020 \\
\text { (may) }\end{array}$ & $\begin{array}{c}\text { Selected } \\
\text { Mining } \\
\text { Municipalities }\end{array}$ \\
\hline $\begin{array}{l}\text { Economic } \\
\text { Activities }\end{array}$ & $\begin{array}{c}\text { Gross Domestic } \\
\text { Product of } \\
\text { Municipalities (IBGE) }\end{array}$ & $\begin{array}{l}\text { 1st and 2nd largest } \\
\text { economic sector }\end{array}$ & $\begin{array}{c}2017 \\
\text { (lastest } \\
\text { available) }\end{array}$ & $\begin{array}{c}\text { Selected } \\
\text { Mining } \\
\text { Municipalities }\end{array}$ \\
\hline
\end{tabular}

Source: Prepared by the authors.

From the open data ${ }^{30}$ on mining royalties in Brazil (ANM, 2019), it was observed that the states of Pará and Minas Gerais occupy the top of the municipal ranking of mineral producers in 2019 and 2020. Therefore, the selection criteria for municipalities with revenues exceeding 30 million reais (5,57 million dollars) in 2019 in these two states was adopted, which resulted in the selection of 19 municipalities, 6 of which are located in the state of Pará: Canaã dos Carajás, Curionópolis, Marabá, Oriximiná, Paragominas e Parauapebas; and 13 in the state of Minas Gerais: Belo Vale, Brumadinho, Catas Altas, Conceição do Mato Dentro, Congonhas, Itabira, Itabirito, Itatiaiuçu, Mariana, Nova Lima, Paracatu, Rio Piracicaba and São Gonçalo do Rio Abaixo.

In order to assess the economic performance of these selected mining municipalities, the Municipal Gross Domestic Product Index (Municipal PIB, IBGE) was evaluated, and for the mineral extraction sector, the open data from National Mining Agency (ANM) and the Ministry of Mines and Energy (MME) was evaluated.

Covid-19 incidence data were evaluated for all municipalities in both states. At the beginning of the pandemic in Brazil, the Ministry of Health (MS) launched the Coronavirus Panel, an online platform gathering the historical series of infections and deaths based on information

\footnotetext{
${ }^{30}$ CFEM collection system of the National Mining Agency (ANM, 2019).
} 
from the State Health Secretariats. The evaluation of the methodological structure of this system was necessary to define the base data to be collected.

The Coronavirus Panel (MS, 2020) is updated daily with information disaggregated by municipality, with the beginning of the data series in February 2020. The platform presents the number of accumulated cases, new cases identified, accumulated deaths, new deaths, recovered and monitored cases. The recovered and monitored cases were incorporated in the system in May, while the number of cases and deaths were registered since the beginning of the records. Regarding new cases of Covid-19 at the municipal level, the panel reports that they do not mean the date of commencement or place of the infection.

Considering some limitations in the data related to the exact location of deaths and the revision of the incidence ${ }^{31}$ of new occurrences, the "accumulated cases" at the municipal level was adopted as the research parameter, which was collected for all municipalities in both states, Pará and Minas Gerais, until July $9^{\text {th }}, 2020$.

The data collection of all municipalities in both states aimed to compare the mining municipalities selected in this research with other municipalities in the same population range, in order to calculate the municipal incidence rate, which corresponds to the number of cases accumulated over the local population. Then, the average number of cases by population of the other municipalities was calculated to compare the results with the selected mining municipalities.

The data collection on the evolution of job supply sought to evaluate the mineral extraction industry scenario compared with the national scenario from the General Register of Employed and Unemployed System (CAGED) which represents the main Brazilian source, with data compiled since 1986. CAGED monitors monthly the evolution of the numbers of unemployed and admissions to the various sectors of economic activities, with data disaggregated at the municipal level. The scope and methodology of data collection on employment have evolved significantly and the last change occurred between 2019 and 2020, with incorporation of information on social security from other bases.

At the municipal level, data collection can be carried out by geographical or occupational level (sector of activity); and from the total number of employees by sector at the beginning of the year, it is possible to calculate the monthly variation, in terms of admissions and dismissals. With the new methodology, the database started to evaluate not only formal hired employees, including temporary workers, independent workers and public agents. Regarding the sectors of economic

${ }^{31}$ More details are described on the official website under "About the Coronavirus Panel" (MS, 2020). 
activities, the new system, CAGED 2020, includes more subcategories, among which the mineral extractive industries sector has been expanded.

For the collection of data in the year 2019 of the selected municipalities of Pará and Minas Gerais, the Ministry of Labor's online information system called 'municipality profile' (CAGED, 2019) was used. On this platform, the total number of employees in the extractive industry and the number of employees formally registered in all activities at the municipal level were collected from January to December 2019. This methodology included the Oil and Gas industries in the same category as the mineral extractive industries.

In relation to the data for the year 2020, with the new subcategories of economic activities in the new CAGED (PDET, 2020), the mineral extraction sector was separated from the oil and gas industry. This change did not affect the quality of the data analyzed, since in these states there is no oil and gas production. In order to compare data, the stock of employees in December 2019 was used as a reference for the calculation of the total and sectoral stock in January 2020. From this reference, the monthly variation in percentage could be calculated for the rest of the year 2020.. Due to the methodological recategorization for the extractive sector, which provided greater detail in the data, only the percentage variation was evaluated, disregarding the quantity of jobs in order to give consistency to the assessment of 2019 and the period from January to June 2020 , according to the data available until the date of the survey.

\section{Covid-19's impact on selected Brazilian mining municipalities}

To evaluate the impacts of Covid-19 on mining municipalities, the tradeoff between economy and health must be considered because social isolation policies are relevant to reduce Covid-19 infections; however, they reduce the level of economic activity as explained by Ornelas (2020), because "a central message is that there is no "health vs. economics" dichotomy".

As explained in Section 4, the criteria for selecting mining municipalities was based on those with more than 30 million reais (5,57 million dollars) of royalties collected in 2019 . Therefore, the following are presented in Table 4: (i) the selected mining municipalities, (ii) the percentage of the royalties (mineral operation / collection of royalties in current dollars) and (iii) the main substances produced in each municipality. 
Table 4. Largest mining municipalities in Brazil based on the collection of royalties.

\begin{tabular}{|c|c|c|c|c|c|c|}
\hline \multirow{2}{*}{ Selected Municipalities } & \multirow{2}{*}{ State } & \multicolumn{3}{|c|}{$\begin{array}{c}\text { Collection of Mining Royalties by } \\
\text { municipality }\end{array}$} & \multicolumn{2}{|c|}{ Main substances } \\
\hline & & $\begin{array}{c}\text { Mineral Operation } \\
\text { (US\$) }\end{array}$ & $\begin{array}{c}\text { Royalties } \\
\text { Collected (US\$) }\end{array}$ & $\%$ & $1^{\text {st }}$ & $2^{\text {nd }}$ \\
\hline Parauapebas & PA & $6.026 .652 .430,33$ & $214.712 .268,55$ & 3,56 & Iron & Manganese \\
\hline Canaã dos Carajás & PA & $3.813 .434 .296,61$ & 131.127.376,99 & 3,43 & Iron & Copper \\
\hline Congonhas & MG & $1.545 .988 .753,89$ & $52.772 .251,48$ & 3,41 & Iron & * \\
\hline Itabira & MG & $1.299 .374 .559,99$ & $44.771 .829,56$ & 3,44 & Iron & Emerald \\
\hline Nova Lima & MG & $1.013 .563 .064,25$ & $36.735 .370,19$ & 3,62 & Iron & Serpentinite \\
\hline $\begin{array}{l}\text { Conceição do Mato } \\
\text { Dentro }\end{array}$ & MG & $959.891 .252,94$ & $33.596 .194,14$ & 3,50 & Iron & * \\
\hline $\begin{array}{l}\text { São Gonçalo do Rio } \\
\text { Abaixo }\end{array}$ & MG & $845.933 .325,59$ & $29.719 .456,97$ & 3,51 & Iron & Sand \\
\hline Marabá & PA & $1.162 .860 .615,07$ & $24.904 .037,58$ & 2,14 & Copper & Manganese \\
\hline Itabirito & MG & $548.831 .124,57$ & $19.854 .172,17$ & 3,61 & Iron & Phyllite \\
\hline Mariana & MG & $432.763 .047,44$ & $15.430 .948,75$ & 3,56 & Iron & Steatite \\
\hline Brumadinho & MG & $397.426 .027,82$ & $13.487 .723,57$ & 3,39 & Iron & Water \\
\hline Belo Vale & MG & $320.675 .000,63$ & 10.991.351,85 & 3,42 & Iron & Manganese \\
\hline Itatiaiuçu & MG & $322.077 .667,68$ & $10.749 .545,81$ & 3,33 & Iron & Water \\
\hline Catas Altas & MG & $284.813 .730,85$ & $9.972 .892,70$ & 3,50 & Iron & * \\
\hline Paracatu & MG & $643.941 .408,56$ & $9.873 .658,96$ & 1,53 & Gold & Zinc \\
\hline Paragominas & PA & $240.693 .740,38$ & 7.221.961,32 & 3,00 & Bauxite & Sand \\
\hline Oriximiná & PA & 229.876.079,48 & $6.823 .560,36$ & 2,96 & Bauxite & Sand \\
\hline Rio Piracicaba & MG & $191.355 .668,87$ & $6.799 .956,16$ & 3,55 & Iron & Steatite \\
\hline Curionópolis & PA & $202.378 .883,40$ & $6.750 .748,26$ & 3,33 & Iron & Copper \\
\hline
\end{tabular}

Source: ANM (2019).

From the selected mining municipalities, data collection was carried out on the number of cases of Covid-19 in the states of Pará and Minas Gerais. The following facts are observed until July $9^{\text {th }}, 2020$, as Table 5 presents:

(i) The number of Covid-19 cases in the state of Pará was 120.731 (accumulated cases), with an average incidence rate of $1,40 \%$, higher than the state of Minas Gerais with 66.864 accumulated cases and an average incidence rate of $0,32 \%$;

(ii) Among the selected mining municipalities, Canaã dos Carajás is the second with the highest incidence of cases $(6,20 \%)$, followed by Parauapebas in third $(5.18 \%)$ and Curionópolis in fifth $(4,22 \%)$, considering the total of 997 municipalities in both states;

(iii) All selected mining municipalities in Pará had a higher average incidence rate of Covid-19 cases than those selected in Minas Gerais. 
Table 5. Ranking of Covid-19 cases incidence of the selected mining municipalities over the total number of municipalities - Pará and Minas Gerais.

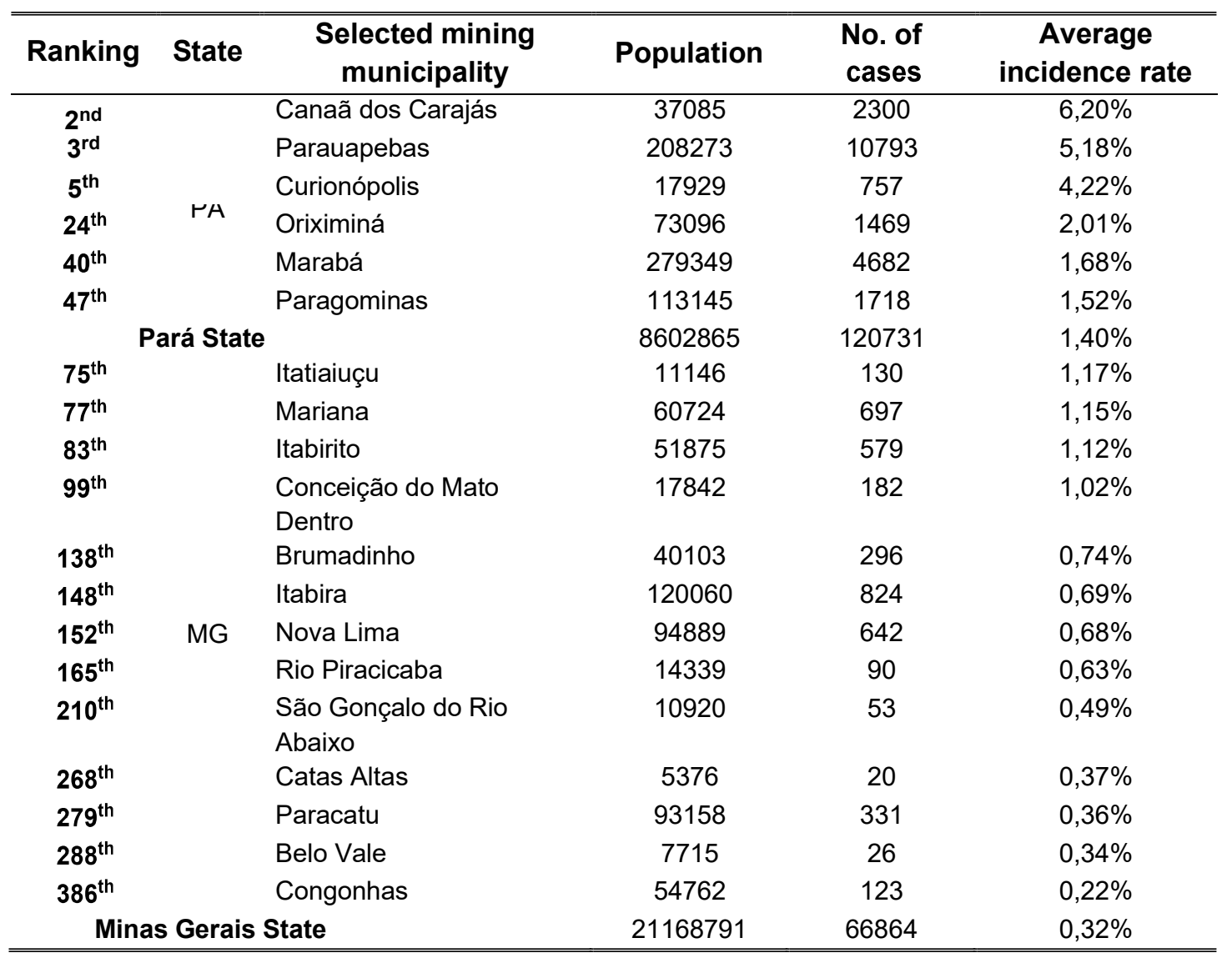

Source: MS (2020); IBGE (2020).

A point to be highlighted in the results is that the selected mining municipalities have a higher average incidence rate for Covid-19, compared to municipalities in the same population range. One possible reason for this is the maintenance of mining activity and the consequent greater circulation of people and other related economic activities, which can increase the incidence rate of Covid-19. Table 6 below shows the ratio between the sum of accumulated cases of Covid-19 of the selected mining municipalities and the others in the same state. The average incidence ratio is greater than or equal to one, pointing that there is a higher incidence of cases of Covid-19 in these municipalities compared to other municipalities in the same population range. 
Table 6. Incidence of Covid-19 ratio between the selected mining municipalities and the others by population range - Pará and Minas Gerais.

\begin{tabular}{|c|c|c|c|c|c|c|c|c|}
\hline \multirow{2}{*}{ population } & \multicolumn{4}{|c|}{ Pará } & \multicolumn{4}{|c|}{ Minas Gerais } \\
\hline & $\begin{array}{c}\text { Total } \\
\text { Municipalities }\end{array}$ & $n n \ldots \ldots$ & $\begin{array}{c}\text { Other } \\
\text { municipalities }\end{array}$ & n.t. & $\begin{array}{c}\text { Total } \\
\text { Municipalities }\end{array}$ & Miner & $\begin{array}{c}\text { Unner } \\
\text { municipalities }\end{array}$ & Ratio \\
\hline 200 to $500 \mathrm{~K}$ & 4 & $3,17 \%$ & $1,05 \%$ & 3,01 & 0 & - & - & - \\
\hline 100 to $200 \mathrm{~K}$ & 12 & $1,52 \%$ & $1,52 \%$ & 1,00 & 20 & $0,69 \%$ & $0,31 \%$ & 2,19 \\
\hline 50 to $100 \mathrm{~K}$ & 28 & $2,01 \%$ & $1,03 \%$ & 1,95 & 38 & $0,67 \%$ & $0,26 \%$ & 2,53 \\
\hline 30 to $50 \mathrm{~K}$ & 34 & $6,20 \%$ & $1,33 \%$ & 4,66 & 0 & - & - & - \\
\hline 10 to $20 \mathrm{~K}$ & 28 & $4,22 \%$ & $1,33 \%$ & 3,18 & 192 & $0,84 \%$ & $0,18 \%$ & 4,60 \\
\hline $\begin{array}{l}\text { Less than } 10 \\
\mathrm{~K}\end{array}$ & 0 & - & - & - & 476 & $0,35 \%$ & $0,15 \%$ & 2,28 \\
\hline
\end{tabular}

$\mathrm{K}=1.000$ inhabitants.

Source: Prepared by the authors, adapted from MS (2020); IBGE (2020).

Another relevant point in the analysis of the results was the number of cases of Covid-19 per municipality in the same population range. These results are illustrated in Appendix II and III with further details, with the following highlights:

(i) In the state of Pará, most of the selected mining municipalities had a higher Covid-19 incidence rate than others in the same population range, with the exception of: (a) Benevides in the Oriximiná population range (from 50 to 100 thousand inhabitants) which presented 2,11\%; (b) and four other municipalities in the same population range of Paragominas (from 100 to 200 thousand inhabitants) ${ }^{32}$ : Itaituba $(3,01 \%)$, Cametá $(2,85 \%)$, Altamira $(1,87 \%)$ and Barcarena $(1,71 \%)$.

(ii) In the state of Minas Gerais, the same pattern of incidence was confirmed, that is, the selected mining municipalities had a higher incidence rate than that of the other municipalities in the same population range, with the exception of the following municipalities: (a) Coronel Fabriciano $(0,83 \%)$ e Muriaé $(0,99 \%)$ in the population range of 100 to 200 thousand; (b) Leopoldina $(0,92 \%)$ in the population range of 50 to 100 thousand;

(c) 60 municipalities in the population range 10 to 20 thousand inhabitants.

\footnotetext{
32 For further informations: 1) The municipality of Itaituba can be considered a mining municipality (26 $6^{\text {th }}$ largest collection of CFEM - gold and tin); 2) Cametá refers to a port city, cut by a federal highway and state network; 3) Altamira is known for its small scale gold mining activities and 4) Barcarena stands out for its mineral processing industry. These details highlight the incidence of cases in mining, manufacturing or other cities that stand out for their port or road infrastructure.
} 
Comparing the COVID-19 incidence rate between the selected municipalities and the other municipalities in the same population range, Table 7 below lists the number of municipalities that present a higher incidence of Covid-19 than the selected mining municipalities.

Table 7. Number of municipalities with a Covid-19's higher incidence rate than the selected mining municipalities - Pará and Minas Gerais.

\begin{tabular}{|c|c|c|c|c|}
\hline \multirow[b]{2}{*}{$\begin{array}{l}\text { Population } \\
\text { Range }\end{array}$} & \multicolumn{2}{|c|}{ Pará } & \multicolumn{2}{|c|}{ Minas Gerais } \\
\hline & $\begin{array}{c}\text { No. of } \\
\text { municipalities }{ }^{1} \text { with } \\
\text { higher incidence }\end{array}$ & $\begin{array}{c}\text { Total of } \\
\text { municipalities }^{2}\end{array}$ & $\begin{array}{c}\text { No. of } \\
\text { municipalities }{ }^{1} \text { with } \\
\text { higher incidence }\end{array}$ & $\begin{array}{c}\text { Total of } \\
\text { municipalities }\end{array}$ \\
\hline 200 to $500 \mathrm{~K}$ & 0 & 4 & - & - \\
\hline 100 to $200 \mathrm{~K}$ & 4 & 12 & 2 & 20 \\
\hline 50 to $100 \mathrm{~K}$ & 1 & 28 & 1 & 38 \\
\hline 30 to $50 \mathrm{~K}$ & 0 & 34 & - & - \\
\hline 10 to $20 \mathrm{~K}$ & 0 & 28 & 3 & 192 \\
\hline $\begin{array}{l}\text { Less than } 10 \\
\mathrm{~K}\end{array}$ & - & - & 60 & 476 \\
\hline
\end{tabular}

$\mathrm{K}=1.000$ inhabitants.

${ }^{1}$ Municipalities in the same population range (not selected).

2 Selected mining municipalities and other municipalities.

Source: Prepared by the authors.

From the results presented in Table 6, it is observed that only 5 out of 106 municipalities in the state of Pará and 66 out of 726 municipalities in Minas Gerais had a higher incidence of Covid-19 cases than the mining municipalities selected in the respective population ranges. This fact can be further explained by other factors related to the epidemiological dynamics of Covid-19 or characteristics of the local socioeconomic dynamics.

Based on these results, there is a correlation between the maintenance of mining as an essential activity during the pandemic and the higher incidence rates of accumulated cases of Covid-19 (by population range) in the selected municipalities.

As can be seen in the previous tables, the high incidence rates in these municipalities sound a warning as to the local consequences of the definition of certain economic activities considered essential, which must be further investigated by the formulators of public policies, whether facing Covid-19 or other possible pandemics.

In addition to the presented results, two maps were drawn for each state that locate the municipalities in order to reveal the patterns of proximity and their possible relationship with the incidence of Covid-19. The following Figures 1 and 2 show the spatial distribution of the selected 
mining municipalities in the state of Minas Gerais (Southeastern Brazil) and Pará (Amazon Region). The higher percentages of Covid-19 within the local population can be seen on the map by the intensity of the color.

The state of Minas Gerais has a greater concentration of mineral occurrence and the cases of Covid-19 are also higher in neighboring cities, which may be related to the maintenance of mineral activities in the southeastern region of the state (Figure 1).

Figure 1. Covid-19 incidence map of selected mining municipalities in Minas Gerais.
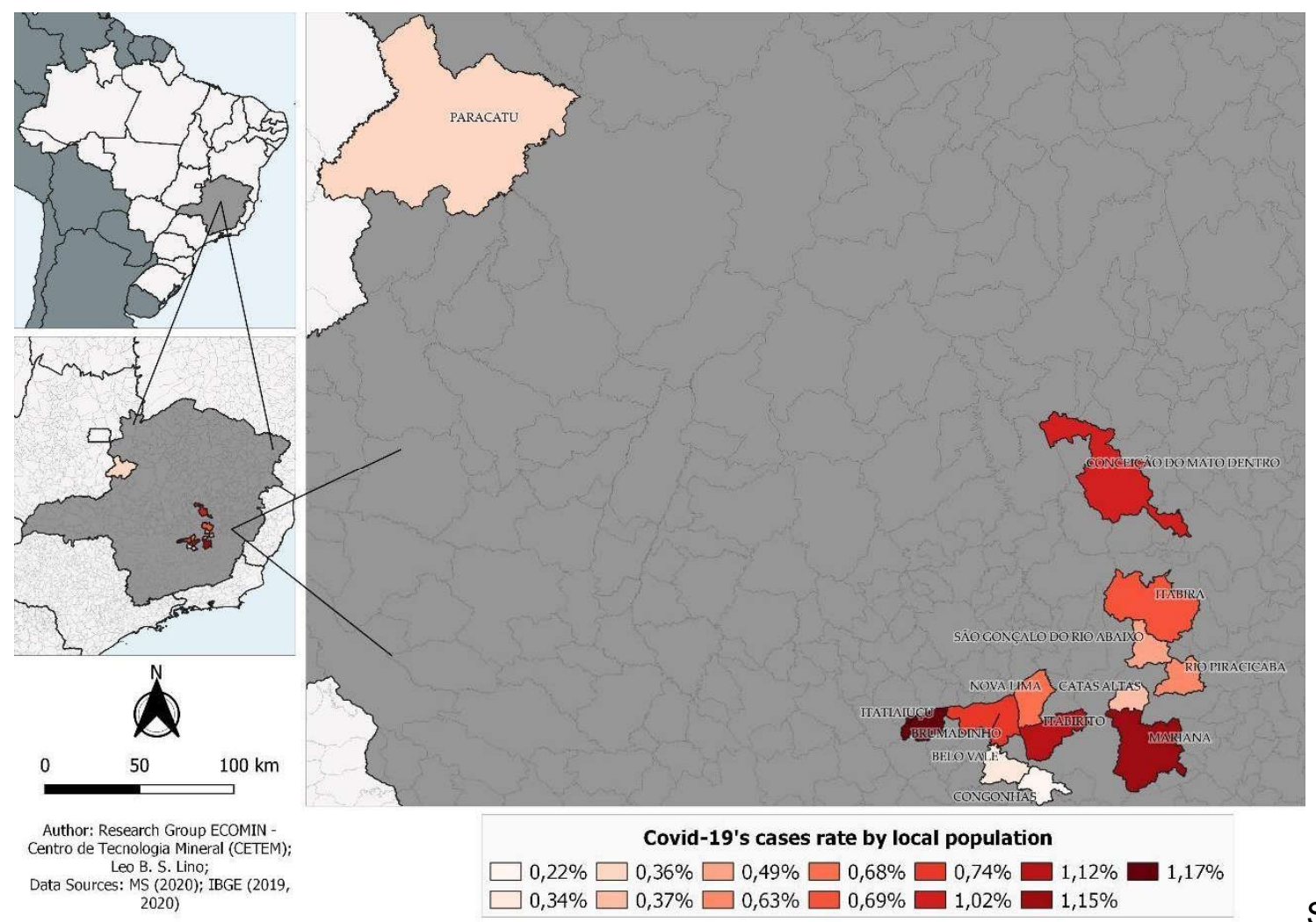

Prepared by ECOMIN/CETEM, adapted from MS (2020).

The state of Pará, located in the Amazon Region, presents a greater spatial dispersion of mining municipalities, although there is also a concentration of mineral occurrence in some municipalities. However, Covid-19 incidence rates are much higher than in Minas Gerais, which can be explained by locational factors related to the greater dispersion of the population in the Amazon Region and the lack of or precariousness of health services. These reasons explain the different spatial pattern, where high rates of Covid-19 incidence occur in remote areas but with intense activity in the mineral extraction sector. 
Figure 2. Covid-19 incidence map of selected mining municipalities in Pará.

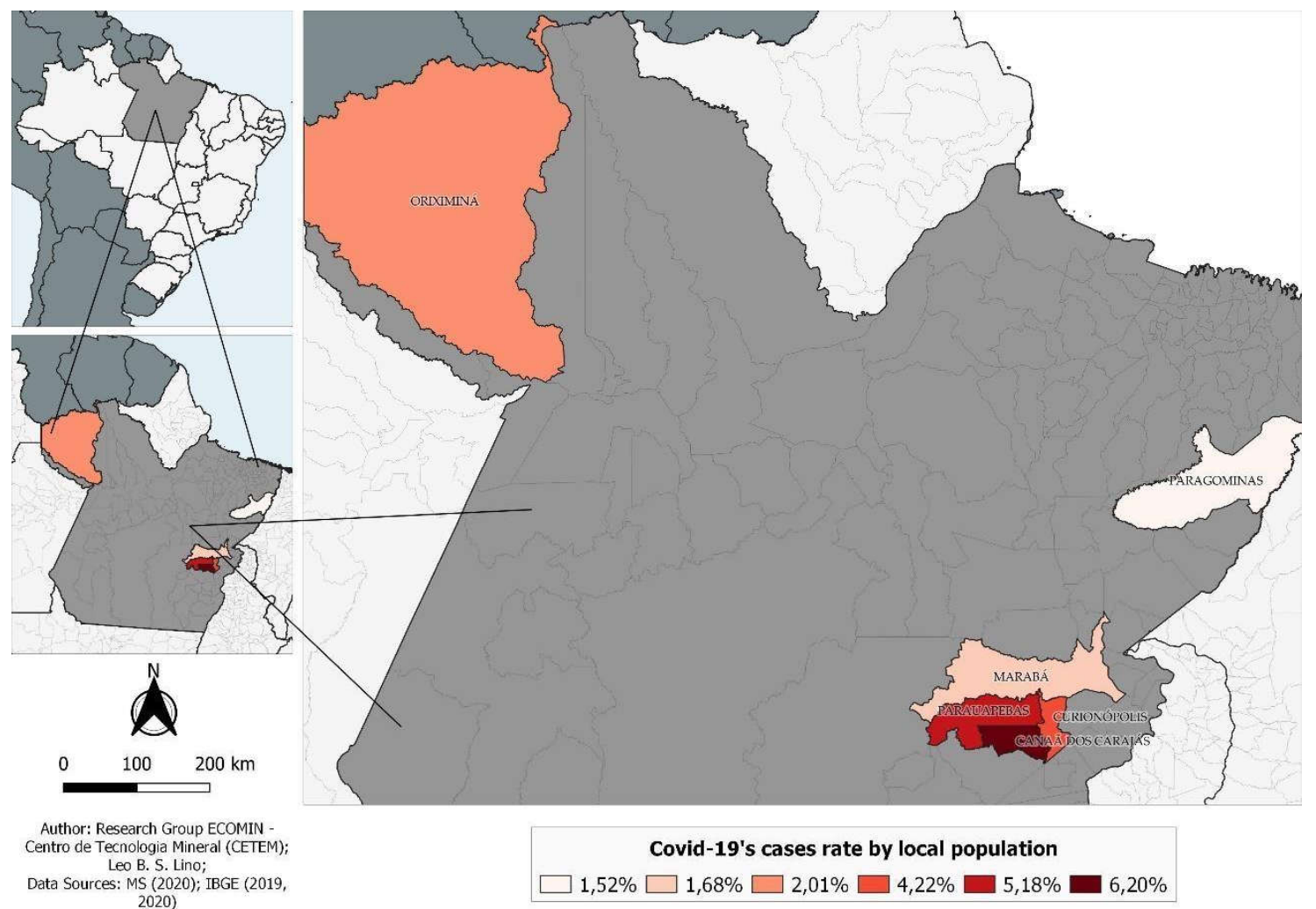

Source:

Prepared by ECOMIN/CETEM, adapted from MS (2020).

The next section presents the variation in total municipal formal employment and in the mining industry.

\section{The evolution of jobs in selected mining municipalities}

In order to broaden the analysis of the employment evolution of the selected mining municipalities, it is necessary to assess the main economic activities (shown in Table 8 ) based on the Municipal Gross Added Value (VAB), a component of the municipal Gross Domestic Product Index. 
Table 8. Major economic activities of the selected mining municipalities.

\begin{tabular}{|c|c|c|c|}
\hline \multicolumn{2}{|c|}{ Selected Mining Municipalities } & \multirow{2}{*}{$\begin{array}{c}\text { First Economic } \\
\text { Activity }\end{array}$} & \multirow{2}{*}{$\begin{array}{c}\text { Second } \\
\text { Economic } \\
\text { Activity } \\
\text { Construction }\end{array}$} \\
\hline \multirow{5}{*}{$\begin{array}{l}\text { Pará } \\
\text { (PA) }\end{array}$} & Canaã dos Carajás & & \\
\hline & Curionópolis & Extractive industries & Other services \\
\hline & Marabá & Other services & $\begin{array}{l}\text { Extractive } \\
\text { industries }\end{array}$ \\
\hline & Oriximiná & Extractive industries & Other services \\
\hline & Paragominas & Other services & $\begin{array}{l}\text { Extractive } \\
\text { industries }\end{array}$ \\
\hline \multirow{15}{*}{$\begin{array}{l}\text { Minas } \\
\text { Gerais } \\
\text { (MG) }\end{array}$} & Parauapebas & Extractive industries & Other services \\
\hline & Belo Vale & $\begin{array}{c}\text { Public } \\
\text { administration }\end{array}$ & Other services \\
\hline & Brumadinho & Extractive industries & Other services \\
\hline & Catas Altas & Extractive industries & Other services \\
\hline & Conceição do Mato & Extractive industries & Other services \\
\hline & Dentro & & \\
\hline & Congonhas & Extractive industries & Other services \\
\hline & Itabira & Extractive industries & Other services \\
\hline & Itabirito & Extractive industries & Other services \\
\hline & Itatiaiuçu & Extractive industries & Other services \\
\hline & Mariana & Extractive industries & Other services \\
\hline & Nova Lima & Extractive industries & Other services \\
\hline & Paracatu & Other services & $\begin{array}{l}\text { Extractive } \\
\text { industries }\end{array}$ \\
\hline & Rio Piracicaba & Extractive industries & Other services \\
\hline & $\begin{array}{l}\text { São Gonçalo do Rio } \\
\text { Abaixo }\end{array}$ & Extractive industries & Other services \\
\hline
\end{tabular}

Source: IBGE (2017).

Based on the assessment of major economic activities, it is pertinent to assess the size of the labor market and the evolution of formal jobs in the selected mining municipalities. It was noted that between 2019 (January to December), the variation in the number of jobs showed high growth rates in the municipalities evaluated, both in total and in relation to jobs in the mining industry.

In 2019, among the 19 municipalities 8 showed a significant increase (above $7 \%$ ) in the total supply of formal jobs and 6 of them obtained a moderate increase (between 3,5 and 7\%). In the mineral extraction industry, 8 municipalities presented a significant increase (above $7 \%$ ) in the jobs offer in the sector and two municipalities had a moderate increase (between 3,5 and 7\%). Only Conceição de Mato Dentro had a significant reduction in the number of jobs $(-10,3 \%)$, while 2 municipalities, Paracatu $(-6,41 \%)$ and Curionópolis $(-3,84 \%)$ showed a moderate reduction. Regarding the reduction of jobs in the mineral extraction sector, only Curionópolis $(-16,63 \%)$ had a significant reduction, which was compatible with the total variation of jobs in the municipality, 
while Brumadinho $(-4,38 \%)$ had a moderate reduction inversely proportional to the total variation in formal jobs.

Between January and May 2020, there was a notable change in the outlook observed in 2019, since 8 of the 19 municipalities evaluated presented a reduction in the total number of jobs, among which Oriximiná had a significant reduction $(-8,42 \%)$ and São Gonçalo do Rio Abaixo had a moderate reduction $(-5,58 \%)$.

As shown in table 9, in relation to the municipalities that increased their jobs supply, there was a slight increase (less than 3,5\%), except for 4 municipalities that presented a significant increase: Conceição de Mato Dentro (12,44\%), Itabirito (8,03\%), Itatiaiuçu (8,23\%) and Paracatu $(12,68 \%)$. For the mineral extraction sector there is also less significant variation, as only Marabá $(-5,98 \%)$ presented a moderate reduction in jobs in the sector and 2 municipalities, Itatiaiuçu $(4,52 \%)$ and Curionópolis $(4,02 \%)$ had a moderate increase in jobs in the sector.

Table 9. Variation of formal jobs in the largest mining municipalities of PA and MG, according to CAGED, from 2019 to 2020.

\begin{tabular}{|c|c|c|c|c|c|c|}
\hline \multirow[b]{2}{*}{ Selected Municipalities } & \multicolumn{3}{|c|}{2019} & \multicolumn{3}{|c|}{2020} \\
\hline & $\begin{array}{c}\text { Pop.i } \\
n \\
\text { forma } \\
\text { I jobs } \\
(\%)\end{array}$ & $\begin{array}{c}\text { Total } \\
\text { jobs } \\
\text { Variation } \\
\text { (Jan- } \\
\text { Dec) } \\
(\%)\end{array}$ & $\begin{array}{c}\text { Extractiv } \\
\text { e sector } \\
\text { jobs } \\
\text { variation } \\
\text { (Jan- } \\
\text { Dec) } \\
(\%)\end{array}$ & $\begin{array}{c}\text { Pop.i } \\
n \\
\text { forma } \\
\text { I jobs } \\
(\%)\end{array}$ & $\begin{array}{c}\text { Total } \\
\text { jobs } \\
\text { Variation } \\
\text { (Jan- } \\
\text { Dec) } \\
(\%)\end{array}$ & $\begin{array}{c}\text { Extractiv } \\
\text { e sector } \\
\text { jobs } \\
\text { variation } \\
\text { (Jan- } \\
\text { Dec) } \\
(\%)\end{array}$ \\
\hline Parauapebas (PA) & 20,68 & 14,58 & 1,35 & 22,27 & 2,48 & 0,63 \\
\hline Canaã dos Carajás (PA) & 29,91 & 13,16 & 13,42 & 30,09 & 0,16 & 1,23 \\
\hline Congonhas (MG) & 26,56 & 0,03 & 9,53 & 28,11 & 2,69 & $-1,26$ \\
\hline Itabira (MG) & 21,30 & 7,17 & 0,00 & 20,70 & $-0,36$ & 0,50 \\
\hline Nova Lima (MG) & 56,11 & 11,88 & 6,73 & 51,80 & $-3,08$ & 1,65 \\
\hline $\begin{array}{l}\text { Conceição do Mato Dentro } \\
\text { (MG) }\end{array}$ & 25,33 & $-10,30$ & 7,65 & 29,23 & 12,44 & 0,69 \\
\hline $\begin{array}{l}\text { São Gonçalo do Rio Abaixo } \\
\text { (MG) }\end{array}$ & 36,01 & 3,69 & 0,00 & 36,40 & $-5,58$ & $-1,56$ \\
\hline Marabá (PA) & 13,72 & 6,69 & 10,93 & 13,63 & $-1,05$ & $-5,98$ \\
\hline Itabirito (MG) & 23,21 & 6,98 & 3,24 & 24,87 & 8,03 & 0,24 \\
\hline Mariana (MG) & 23,27 & 15,16 & 2,75 & 25,36 & 6,75 & 0,20 \\
\hline Brumadinho (MG) & 21,03 & 6,59 & $-4,38$ & 21,88 & 0,69 & $-1,97$ \\
\hline Belo Vale (MG) & 8,11 & 12,19 & 18,79 & 8,04 & 0,32 & 1,01 \\
\hline Itatiaiuçu (MG) & 25,67 & 9,53 & 9,99 & 27,72 & 8,23 & 4,52 \\
\hline Catas Altas (MG) & 12,33 & 5,91 & 5,59 & 13,02 & 2,34 & $-2,72$ \\
\hline Paracatu (MG) & 20,12 & $-6,41$ & $-1,23$ & 24,99 & 12,68 & $-1,75$ \\
\hline Paragominas (PA) & 14,06 & 2,85 & 12,96 & 13,59 & $-1,54$ & 0,32 \\
\hline Oriximiná (PA) & 6,95 & 9,77 & 9,53 & 6,24 & $-8,42$ & $-1,76$ \\
\hline Rio Piracicaba (MG) & 12,94 & 2,04 & $-1,57$ & 13,01 & $-0,27$ & 1,40 \\
\hline Curionópolis (PA) & 16,75 & $-3,84$ & $-16,63$ & 14,84 & $-2,10$ & 4,02 \\
\hline
\end{tabular}

Source: CAGED (2019); PDET (2020). 
Based on the evolution of formal jobs presented in table 9, it was found that 2019 was a year of growth in the jobs supply in the mineral extractive sector, while 2020 showed significant fluctuations in the variation of total formal jobs and a less pronounced variation in the extractive sector, which indicates that the extractive sector remained stable in relation to the previous year.

\section{Conclusions}

This paper discussed the interaction between mining and the accumulated cases of the new coronavirus in the population of the major mining municipalities in Brazil, after being considered an essential activity to face Covid-19 challenge in the country. The analysis and discussion of the results showed that:

(i) Between 997 municipalities in Pará and Minas Gerais, a higher degree of Covid-19 cases incidence was relatively greater in the selected mining municipalities.

(ii) There is a higher ratio of Covid-19 cases in the selected mining municipalities than in the other cities in the same population range in Pará and Minas Gerais states;

(iii) The jobs supply in the mining sector from the selected mining municipalities remained stable compared to the period before the pandemic, which in some cases was inversely proportional to total formal jobs in the selected municipality. This could indicate that employees were maintained in the mining sector during the pandemic.

Among the aspects described in the present paper, it is signaled that there is a link, although not yet fully established, between the risks of infection and the maintenance of economic activities, which, in the case of mining, can be better observed by monitoring the situation in mining municipalities compared to other municipalities in the same region. This paper analyzed the selected major mining municipalities and the other municipalities in the same state by population range. In order to broaden this analysis, it is important to extend this scope to other dimensions besides population range.

The results warn that mining activity, although essential and fundamental for people's livelihood and for the economy to function, is carried out within the parameters of people's integrity and quality of life, aimed at long-term local sustainability to overcome the pandemic. Continuation of this research may offer recommendations for decision-making by public agents and local governments.

\section{References}


ANM - Agência Nacional de Mineração. Sistema de Arrecadação da CFEM. [online]. 2019. Available <https://sistemas.anm.gov.br/arrecadacao/extra/Relatorios/cfem/maiores_arrecadadores.a spx>. Accessed on July $10^{\text {th }}, 2020$.

BRASIL. Lei n 13.979, de 6 de fevereiro de 2020, dispõe sobre as medidas de enfrentamento da pandemia do coronavírus. Brasília: Presidência da Repúblilca. 2020a.

BRASIL. Decreto $n^{010.282}$, de 20 de março de 2020, dispõe sobre os serviços públicos e atividades essenciais. Brasília: Presidência da República. 2020b.

BRASIL. Decreto $n^{\circ} 10.329$, de 28 de abril de 2020, altera o decreto $n^{\circ} 10.282$ e regulamenta a lei 13.979. Brasília: Presidência da República. 2020c.

BRASIL. Lei $n^{\circ} 13.540$, de 18 de dezembro de 2017, dispõe sobre a Compensação Financeira pela Exploração de Recursos Minerais (CFEM). Brasília: Senado Federal. 2017.

CAGED - Cadastro Geral de Empregados e Desempregados. Perfil dos municípios. [online]. Ministério do Trabalho. 2019. Available at: $<$ http://bi.mte.gov.br/bgcaged/caged_perfil_municipio/index.php>. Accessed on July $1^{\text {st }}$, 2020.

IBGE - Instituto Brasileiro de Geografia e Estatística. Estimativa populacional municipal. [online]. SIDRA/IBGE. 2020. Available at: < https://sidra.ibge.gov.br/>. Accessed on July 10 2020.

IBGE - Instituto Brasileiro de Geografia e Estatística. Produto Interno Bruto dos Municípios. [online]. SIDRA/IBGE. 2017.

IBRAM - Instituto Brasileiro de Mineração. Setor Mineral - $2^{\circ}$ trimestre 2020. [online]. IBRAM. July 21, 2020. Available at: <http://portaldamineracao.com.br/wp-content/uploads/2020/07/pptfinal-completo-site-e-portal.pdf>. Accessed on July $1^{\text {st }}, 2020$.

IMF - International Monetary Fund. Primary Commodity Price System. [online]. IMF Data access to macroeconomic \& financial data. 2020. Available at: <https://data.imf.org/?sk=471DDDF8-D8A7-499A-81BA-5B332C01F8B9>. Accessed on May $27^{\text {th }}, 2020$.

LOAYZA, Norman V.; PENNINGS, Steven. Macroeconomic Policy in the Time of COVID-19: A Primer for Developing Countries. Research and Policy Briefs, No. 28. Washington: World Bank. 2020.

MME - Ministério de Minas e Energia. Portaria n 135/GM, de 28 de março de 2020, dispõe sobre as atribuições da atividade mineral como essencial. Brasília: MME. 2020.

MS - Ministério da Saúde. Painel Coronavírus. [online]. 2020. Available at: $<$ https://covid.saude.gov.br/>. Accessed on July $9^{\text {th }}, 2020$.

MS - Ministério da Saúde. Notas metodológicas. [online]. Painel Coronavírus. 2020.

ORNELAS, E. Lockdown 101: Managing economic lockdowns in an epidemic. RSP - Revista do Serviço Público, Brasília, v. 71, special edition "Governments and Covid-19". 2020. 
Available at: <https://revista.enap.gov.br/index.php/RSP/article/view/4879/2650>. Accessed on August $17^{\text {th }}, 2020$.

PDET - Programa de Disseminação das Estatísticas de Trabalho. Novo CAGED. Painel de Informações do Novo CAGED. [online]. Ministério do Trabalho. 2020. Available at: $<$ http://pdet.mte.gov.br/novo-caged>. Accessed on July $7^{\text {th }}, 2020$.

UN - United Nations. Progress towards the sustainable development goals. [e/2020/57]. Economic and Social Council. United Nations. 2020.

UN - United Nations. 2016. The Sustainable Development Goals Report 2016. New York: United Nations. 2016.

UNCTAD - United Nations Conference on Trade and Development. World Investment Report 2020 - International production beyond the pandemic. New York: UNCTAD. 2020. Available at: <https://unctad.org/en/PublicationsLibrary/wir2020_en.pdf $>$. Accessed on June $30^{\text {th }}$, 2020.

UNDP - United Nations Development Program; Columbia University et al. Mapping Mining to the SDGs: An Atlas. New York: UNDP. 2017. Available at: <https://www.undp.org/content/dam/undp/library/Sustainable\%20Development/Extractives/ Mapping_Mining_SDGs_An_Atlas_Executive_Summary_FINAL.pdf> Accessed on July $15^{\text {th }}, 2020$.

WORLD BANK. O impacto da pandemia de COVID-19 na economia brasileira: preservando a vida e o sustento. [Online]. Rafael M. Moreno. World Bank. May 5, 2020. Available at: $<$ https://blogs.worldbank.org/pt/latinamerica/o-impacto-da-pandemia-de-covid-19-naeconomia-brasileira-preservando-vida-e-o-sustento>. Accessed on May 15 ${ }^{\text {th }}, 2020$.

\section{Appendix}

Appendix I. The SDG's possible actions for the Brazilian mineral sector during the pandemic.

SDG goals whose achievement is directly affected by the Covid-19 pandemic

The pandemic undermines equitable access to employment, the provision of training programs, the directing of royalties (CFEM) towards sustainable

SDG 1 development and other consequences that affect local labor. The mineral sector should provide subsidies for the subsistence of local workers involved in mining operations that were affected by the pandemic.

The loss of jobs and income has a side effect of worsening food security, if

SDG 2 unaccompanied by another source of income in economic activities that were paralyzed by Pandemic. In this sense, the action of emergency public policies is essential to mitigate the effects of the crisis.

While it is necessary to establish that some economic activities are essential for the maintenance of the economy and the livelihood of the population,

SDG 3 aspects of the health risks of workers must also be considered, which must be evaluated in the context of economic activities that need to remain active, 
since they expose workers to risks of contamination, such as what is happening in mining and other activities that are in operation.

Pandemic effects on the mining-related labor market are twofold. The first is directly related to the health risk of workers and the loss of hours worked due to illness in mining municipalities. The other way is related to the demand for mineral goods, which is being affected by the generalized drop

SDG 8 in national and global economic activity, which has negative effects on the labor market for a product subject to volatility in the international commodities market. The guarantee of health to workers and actions to promote essential jobs are vital for the economic recovery after the pandemic.

\section{SDG goals indirectly affected by the Covid-19 pandemic}

Pandemic coping measures will certainly need an input of knowledge and production planning with technological improvements, not only in the safety

SDG 9 and health of workers, but also in the choice and prioritization of the production of mineral goods that will be necessary for the recovery of economic activity, in the context of the new normality that is taking shape. The worsening inequality and the higher social cost of Pandemic has caused approximately 71 million people to return to extreme poverty in 2020, the first increase in global poverty since 1998 (UN, 2020). Loss of

SDG income, limited social protection and rising prices mean that even those who were safe can be at risk of facing poverty and hunger. Public policies to reduce inequalities, focused on the areas where mining is developed, must prioritize the internalization of the benefits of this economic activity. The more efficient use of royalties can be an instrument to reduce inequalities in the context of vulnerable population groups and disadvantaged regions.

The pandemic unequivocally revealed several weaknesses in the current economic model. The closing of borders, the availability of goods and confinement have caused a change in habits around the world. Some of these changes have accelerated new and emerging sectors that support responsible consumption, which, together with alternative forms of work, study and consumption, can reach a level that allows a leap towards

SDG sustainability. Some recovery alternatives for the post-pandemic period 12 should be based on new sustainability paradigms, such as investments to encourage circularity, an inclusive approach aimed at sustainable consumption and the alignment of public and private finances with resilient and sustainable societies. This moment represents an opportunity to meet this demand by stimulating renewable energy, smart buildings and cities, green public transport, local sustainable food and agricultural systems as well as alternative lifestyle options. All of these are related to the sustainable 
use of mineral resources, especially with regard to their rational use, the technology applied and the search for new materials for emerging technologies, among others.

To confront the Pandemic, mining companies, especially the largest ones, can help by contributing to peaceful societies by remedying companycommunity conflicts, providing access to information, respecting human rights, supporting representatives in decision-making and carefully SDG managing their security approach to ensure a decrease in Covid-19 cases. 16 The health care of workers in the mineral activity and, consequently, in the mining municipalities, depends on mechanisms of transparency and information sharing about the real effects of activities that impact society, as well as the public discussion of the prevention of the risks assumed by the continuity of activities. It is necessary to ensure transparency in the use of revenues related to local commitments.

Source: Adapted from UNDP (2017); UN (2020).

Appendix II. Covid-19 cases between the largest mining municipalities in the state of Pará and the other municipalities by population range.

\begin{tabular}{|c|c|c|c|c|c|c|c|c|}
\hline \multirow[b]{2}{*}{$\begin{array}{l}\text { Population } \\
\text { range }\end{array}$} & \multicolumn{7}{|c|}{ Pará } & \multirow[b]{2}{*}{$\begin{array}{l}\text { Covid-19 } \\
\text { / Pop. } \\
\text { (\%) }\end{array}$} \\
\hline & $\begin{array}{c}\text { Mining } \\
\text { municipalities }\end{array}$ & $\begin{array}{l}\text { No. of } \\
\text { Cases }\end{array}$ & Population & $\begin{array}{l}\text { Covid-19 } \\
\text { / Pop. (\%) }\end{array}$ & $\begin{array}{c}\text { Other } \\
\text { municipalities }\end{array}$ & $\begin{array}{l}\text { No. of } \\
\text { Cases }\end{array}$ & Population & \\
\hline 200 to 500 & Marabá & 4682 & 279349 & $1,68 \%$ & Castanhal & 1659 & 200793 & $0,83 \%$ \\
\hline \multirow{7}{*}{$\begin{array}{r}\mathbf{k} \\
\text { inhabitants } \\
\text { average }\end{array}$} & Parauapebas & 10793 & 208273 & $5,18 \%$ & Santarém & 3664 & 304589 & $1,20 \%$ \\
\hline & & & & $3,17 \%$ & & & & $1,05 \%$ \\
\hline & & & & & Abaetetuba & 2378 & 157698 & $1,51 \%$ \\
\hline & & & & & Altamira & 2145 & 114594 & $1,87 \%$ \\
\hline & & & & & Barcarena & 2134 & 124680 & $1,71 \%$ \\
\hline & & & & & Bragança & 1842 & 127686 & $1,44 \%$ \\
\hline & & & & & Breves & 1376 & 102701 & $1,34 \%$ \\
\hline \multirow{6}{*}{$\begin{array}{l}100 \text { A } 200 \text { k } \\
\text { inhabitants }\end{array}$} & Paragominas & 1718 & 113145 & $1518 \%$ & Cametá & 3925 & 137890 & $2,85 \%$ \\
\hline & a a a & 1170 & & (2, & Itaituba & 3052 & 101247 & $3,01 \%$ \\
\hline & & & & & Marituba & 687 & 131521 & $0,52 \%$ \\
\hline & & & & & $\begin{array}{l}\text { São Félix do } \\
\text { Xingu }\end{array}$ & 681 & 128481 & $0,53 \%$ \\
\hline & & & & & Tailândia & 1107 & 106339 & $1,04 \%$ \\
\hline & & & & & Tucuruí & 1206 & 113659 & $1,06 \%$ \\
\hline \multirow[t]{4}{*}{ average } & & & & $1,518 \%$ & & & & $1,52 \%$ \\
\hline & & & & & Acará & 492 & 55591 & $0,89 \%$ \\
\hline & & & & & Alenquer & 634 & 56789 & $1,12 \%$ \\
\hline & & & & & Benevides & 1321 & 62737 & $2,11 \%$ \\
\hline \multirow{2}{*}{50 to $100 \mathrm{k}$} & & & & & Breu Branco & 216 & 66046 & $0,33 \%$ \\
\hline & Oriximiná & & 73096 & & Capanema & 887 & 69027 & $1,29 \%$ \\
\hline \multirow[t]{4}{*}{ inhabitants } & Uriximina & 1469 & 13090 & 2,U1\% & Capitão Poço & 519 & 54303 & $0,96 \%$ \\
\hline & & & & & Dom Eliseu & 635 & 59719 & $1,06 \%$ \\
\hline & & & & & Igarapé-Miri & 1043 & 62698 & $1,66 \%$ \\
\hline & & & & & Ipixuna do Pará & 417 & 64053 & $0,65 \%$ \\
\hline
\end{tabular}




\begin{tabular}{|c|c|c|c|c|c|c|c|c|}
\hline & & & & & Itupiranga & 242 & 53269 & $0,45 \%$ \\
\hline & & & & & Jacundá & 536 & 59155 & $0,91 \%$ \\
\hline & & & & & Juruti & 765 & 57943 & $1,32 \%$ \\
\hline & & & & & Moju & 1169 & 82094 & $1,42 \%$ \\
\hline & & & & & Monte Alegre & 666 & 58032 & $1,15 \%$ \\
\hline & & & & & $\begin{array}{l}\text { Novo } \\
\text { Repartimento }\end{array}$ & 197 & 75919 & $0,26 \%$ \\
\hline & & & & & Óbidos & 381 & 52137 & $0,73 \%$ \\
\hline & & & & & Portel & 832 & 62043 & $1,34 \%$ \\
\hline & & & & & Redenção & 1590 & 84787 & $1,88 \%$ \\
\hline & & & & & $\begin{array}{l}\text { Rondon do } \\
\text { Pará }\end{array}$ & 210 & 52357 & $0,40 \%$ \\
\hline & & & & & Rurópolis & 503 & 50510 & $1,00 \%$ \\
\hline & & & & & $\begin{array}{l}\text { Santa Izabel do } \\
\text { Pará }\end{array}$ & 463 & 70801 & $0,65 \%$ \\
\hline & & & & & $\begin{array}{l}\text { Santana do } \\
\text { Araguaia }\end{array}$ & 174 & 72817 & $0,24 \%$ \\
\hline & & & & & $\begin{array}{l}\text { São Miguel do } \\
\text { Guamá }\end{array}$ & 1028 & 58986 & $1,74 \%$ \\
\hline & & & & & Tomé-Açu & 703 & 63447 & $1,11 \%$ \\
\hline & & & & & Ulianópolis & 519 & 59210 & $0,88 \%$ \\
\hline & & & & & Vigia & 255 & 53686 & $0,47 \%$ \\
\hline & & & & & Viseu & 934 & 61403 & $1,52 \%$ \\
\hline average & & & & $2,01 \%$ & & & & $1,03 \%$ \\
\hline $\begin{array}{c}30 \text { to } 50 \mathrm{k} \\
\text { inhabitants }\end{array}$ & $\begin{array}{l}\text { Canaã dos } \\
\text { Carajás }\end{array}$ & 2300 & 37085 & $6,20 \%$ & $\begin{array}{l}33 \\
\text { municipalities }\end{array}$ & 16110 & 1211736 & $1,33 \%$ \\
\hline average & & & & $6,20 \%$ & & & & $1,33 \%$ \\
\hline $\begin{array}{c}10 \text { to } 20 \mathrm{k} \\
\text { inhabitants }\end{array}$ & Curionópolis & 757 & 17929 & & $\begin{array}{l}27 \\
\text { municipalities }\end{array}$ & 5441 & 409883 & $1,33 \%$ \\
\hline average & & & & $4,22 \%$ & & & & $1,33 \%$ \\
\hline
\end{tabular}

Appendix III. Covid-19 cases between the largest mining municipalities in the state of Minas Gerais and the other municipalities by population range.

Minas Gerais

\begin{tabular}{|c|c|c|c|c|c|c|c|c|}
\hline & & \multirow[b]{2}{*}{$\begin{array}{l}\text { No. of } \\
\text { Cases }\end{array}$} & \multicolumn{3}{|c|}{ nas Gerais } & \multirow[b]{2}{*}{$\begin{array}{l}\text { No. of } \\
\text { Cases }\end{array}$} & \multirow[b]{2}{*}{ Population } & \multirow[b]{2}{*}{$\begin{array}{c}\text { Covid- } \\
19 / \\
\text { Pop. } \\
(\%)\end{array}$} \\
\hline $\begin{array}{l}\text { Population } \\
\text { range }\end{array}$ & $\begin{array}{c}\text { Mining } \\
\text { municipalities }\end{array}$ & & Population & $\begin{array}{c}\text { Covid-19 } \\
\text { / Pop. } \\
\text { (\%) }\end{array}$ & $\begin{array}{c}\text { Other } \\
\text { municipalities }\end{array}$ & & & \\
\hline \multirow{13}{*}{$\begin{array}{c}100 \text { to } 200 \\
k \\
\text { inhabitants }\end{array}$} & \multirow{13}{*}{ Itabira } & \multirow{13}{*}{824} & \multirow{13}{*}{120060} & \multirow{13}{*}{$0,69 \%$} & Araguari & 750 & 117267 & $0,64 \%$ \\
\hline & & & & & Araxá & 283 & 106229 & $0,27 \%$ \\
\hline & & & & & Barbacena & 396 & 137313 & $0,29 \%$ \\
\hline & & & & & $\begin{array}{l}\text { Conselheiro } \\
\text { Lafaiete }\end{array}$ & 175 & 128589 & $0,14 \%$ \\
\hline & & & & & $\begin{array}{l}\text { Coronel } \\
\text { Fabriciano }\end{array}$ & 913 & 109855 & $0,83 \%$ \\
\hline & & & & & Ibirité & 386 & 180204 & $0,21 \%$ \\
\hline & & & & & Ituiutaba & 123 & 104671 & $0,12 \%$ \\
\hline & & & & & Lavras & 148 & 103773 & $0,14 \%$ \\
\hline & & & & & Muriaé & 1081 & 108763 & $0,99 \%$ \\
\hline & & & & & Nova Serrana & 120 & 102693 & $0,12 \%$ \\
\hline & & & & & Passos & 84 & 114679 & $0,07 \%$ \\
\hline & & & & & Patos de & 674 & 152488 & $0,44 \%$ \\
\hline & & & & & Minas & & & \\
\hline
\end{tabular}




\begin{tabular}{|c|c|c|c|c|c|c|c|c|}
\hline \multirow[t]{18}{*}{ Average } & & & & $0,69 \%$ & & & & $0,31 \%$ \\
\hline & \multirow{8}{*}{ Brumadinho } & \multirow{8}{*}{296} & \multirow{8}{*}{40103} & \multirow{7}{*}{$0,74 \%$} & Alfenas & 74 & 79996 & $0,09 \%$ \\
\hline & & & & & Bom & 95 & 50605 & $0,19 \%$ \\
\hline & & & & & Despacho & & & \\
\hline & & & & & Campo Belo & 202 & 54029 & $0,37 \%$ \\
\hline & & & & & Caratinga & 403 & 92062 & $0,44 \%$ \\
\hline & & & & & Cataguases & 130 & 75123 & $0,17 \%$ \\
\hline & & & & & Curvelo & 184 & 80129 & $0,23 \%$ \\
\hline & & & & \multirow{5}{*}{$0,22 \%$} & Esmeraldas & 121 & 70552 & $0,17 \%$ \\
\hline & \multirow[t]{4}{*}{ Congonhas } & \multirow[t]{4}{*}{123} & \multirow[t]{4}{*}{54762} & & Formiga & 222 & 67683 & $0,33 \%$ \\
\hline & & & & & Frutal & 147 & 59496 & $0,25 \%$ \\
\hline & & & & & Guaxupé & 129 & 51917 & $0,25 \%$ \\
\hline & & & & & Itajubá & 114 & 96869 & $0,12 \%$ \\
\hline & \multirow{4}{*}{ Itabirito } & \multirow{4}{*}{579} & \multirow{4}{*}{51875} & \multirow{4}{*}{$1,12 \%$} & Itaúna & 134 & 93214 & $0,14 \%$ \\
\hline & & & & & Janaúba & 263 & 71648 & $0,37 \%$ \\
\hline & & & & & Januária & 19 & 67742 & $0,03 \%$ \\
\hline & & & & & $\begin{array}{l}\text { João } \\
\text { Monlevade }\end{array}$ & 343 & 79910 & $0,43 \%$ \\
\hline & \multirow{7}{*}{ Mariana } & \multirow{7}{*}{697} & \multirow{7}{*}{60724} & \multirow{7}{*}{$1,15 \%$} & $\begin{array}{l}\text { Lagoa da } \\
\text { Prata }\end{array}$ & 283 & 52165 & $0,54 \%$ \\
\hline \multirow{17}{*}{$\begin{array}{l}50 \text { to } 100 \mathrm{k} \\
\text { inhabitants }\end{array}$} & & & & & Lagoa Santa & 108 & 64527 & $0,17 \%$ \\
\hline & & & & & Leopoldina & 483 & 52587 & $0,92 \%$ \\
\hline & & & & & Manhuaçu & 285 & 90229 & $0,32 \%$ \\
\hline & & & & & Ouro Preto & 192 & 74281 & $0,26 \%$ \\
\hline & & & & & Pará de Minas & 78 & 93969 & $0,08 \%$ \\
\hline & & & & & Patrocínio & 232 & 90757 & $0,26 \%$ \\
\hline & \multirow{5}{*}{ Nova Lima } & \multirow{4}{*}{642} & \multirow{4}{*}{94889} & \multirow{5}{*}{$0,68 \%$} & $\begin{array}{l}\text { Pedro } \\
\text { Leopoldo }\end{array}$ & 123 & 64258 & $0,19 \%$ \\
\hline & & & & & Pirapora & 114 & 56428 & $0,20 \%$ \\
\hline & & & & & Ponte Nova & 175 & 59742 & $0,29 \%$ \\
\hline & & & & & São Francisco & 37 & 56323 & $0,07 \%$ \\
\hline & & \multirow{7}{*}{331} & & & $\begin{array}{l}\text { São João del } \\
\text { Rei } \\
\text { São }\end{array}$ & 269 & 90082 & $0,30 \%$ \\
\hline & \multirow{6}{*}{ Paracatu } & & & & $\begin{array}{l}\text { Sebastião do } \\
\text { Paraíso }\end{array}$ & 60 & 70956 & $0,08 \%$ \\
\hline & & & & & Timóteo & 428 & 89842 & $0,48 \%$ \\
\hline & & & 93158 & $0,36 \%$ & $\begin{array}{l}\text { Três } \\
\text { Corações }\end{array}$ & 181 & 79482 & $0,23 \%$ \\
\hline & & & & & Três Pontas & 66 & 56746 & $0,12 \%$ \\
\hline & & & & & Unaí & 562 & 84378 & $0,67 \%$ \\
\hline & & & & & Viçosa & 74 & 78846 & $0,09 \%$ \\
\hline Average & & & & $0,67 \%$ & & & & $0,26 \%$ \\
\hline & $\begin{array}{l}\text { Conceição } \\
\text { do Mato } \\
\text { Dentro }\end{array}$ & 182 & 17842 & $1,02 \%$ & & & & \\
\hline $\begin{array}{l}10 \text { to } 20 \mathrm{k} \\
\text { inhabitants }\end{array}$ & $\begin{array}{l}\text { São Gonçalo } \\
\text { do Rio } \\
\text { Abaixo }\end{array}$ & 53 & 10920 & $0,49 \%$ & $\begin{array}{l}188 \\
\text { municipalities }\end{array}$ & 3872 & 2514333 & $0,15 \%$ \\
\hline & Itatiaiuçu & 130 & 11146 & $1,17 \%$ & & & & \\
\hline & $\begin{array}{l}\text { Rio } \\
\text { Piracicaba }\end{array}$ & 90 & 14339 & $0,63 \%$ & & & & \\
\hline Average & & & & $0,35 \%$ & & & & $0,15 \%$ \\
\hline
\end{tabular}




\begin{tabular}{|c|c|c|c|c|c|c|c|c|}
\hline Less than & Belo Vale & 26 & 7715 & $0,34 \%$ & 474 & & & \\
\hline $\begin{array}{c}10 \mathrm{~K} \\
\text { inhabitants }\end{array}$ & Catas Altas & 20 & 5376 & $0,37 \%$ & municipalities & 3872 & 2514333 & $0,15 \%$ \\
\hline Average & & & & $0,35 \%$ & & & & $0,15 \%$ \\
\hline
\end{tabular}

Source: MS (2020); IBGE (2020).

\section{Fernando Ferreira de Castro}

https://orcid.org/0000-0002-5144-4862

M.Sc. Psychosociology, EICOS/UFRJ, Brazil and Researcher at Mineral Technology

Center (CETEM - MCTI), Brazil.

E-mail: fcastro@cetem.gov.br

\section{José Antônio Sena do Nascimento}

https://orcid.org/0000-0001-8050-3262

D.Sc. Environmental Engineering COPPE/UFRJ, Professor at ENCE/IBGE and Researcher at Mineral Technology Center (CETEM - MCTI), Brazil.

E-mail: jasena@cetem.gov.br

\section{Geraldo Sandoval Góes}

https://orcid.org/0000-0002-5367-8654

D.Sc. Economy at UnB and Researcher at Institute of Applied Economic Research (IPEA), Brazil.

E-mail: geraldo.goes@ipea.gov.br

\section{Mônica Tardin Monnerat}

https://orcid.org/0000-0002-5826-758X

C,T\&I Analyst, D.Sc. Economy at UFRJ and Researcher at Mineral Technology Center (CETEM - MCTI), Brazil.

E-mail:monnerat@cetem.gov.br 